Jurnal REKSA: Rekayasa Keuangan, Syariah, dan Audit

Vol. 8, No. 2, 2021, pp. 67-77

JURNAL REKSA

p-ISSN: 2089-6581 | e-ISSN: 2614-3720

\title{
PENGARUH MOTIVASI, KOMPLEKSITAS TUGAS, DAN INSENTIF MONETER TERHADAP KINERJA INDIVIDU
}

Aulia Azzardina

Universitas Negeri Malang

Email: aulia.azzardina.fe@um.ac.id

\begin{abstract}
This study investigates the relationship between motivation and task complexity on performance. Monetary incentives are involved in this study as a moderating variable. The motivation examined in this research is intrinsic and extrinsic motivation. A $2 \times 2$ quasi-experiment has been conducted and involving 66 university students. Two and three-way ANOVA are used for hypothetical testing. The result shows that individuals with intrinsic motivation have shown better performance than those with extrinsic motivation. After individuals have faced more complex tasks, they achieved lower scores than those who faced less complex tasks. Prior studies suggested that motivation could be destructed by monetary incentives. However, there is no interaction proof when moderating variable is involved. The relationship between motivation and performance is not influenced by monetary incentives. In line with it, the relationship between task complexity and performance is also not strengthened or weakened by the given monetary incentives information. Thus, monetary incentives failed to influence the relationship between motivation, task complexity and performance.
\end{abstract}

Keywords: Motivation, Task Complexity, Monetary Incentives, Goal-Setting Theory, Self-Determination Theory

\section{PENDAHULUAN}

Seseorang dapat merasa termotivasi karena mereka merasa suatu aktivitas berharga atau karena terdapat dorongan eksternal yang kuat (Ryan \& Deci, 2000). Motivasi intrinsik menyebabkan seseorang melakukan aktivitas karena menganggap bahwa hal tersebut menarik dan mendatangkan kepuasan secara spontan (Gagne \& Deci, 2005). Sejalan dengan hal tersebut, Kunz (2015) menyatakan bahwa motivasi intrinsik datang dari kenyamanan atas tugas pada seseorang yang termotivasi secara intrinsik yang merasa terikat dengan tugas karena orang tersebut menyukainya, sedangkan motivasi ekstrinsik memerlukan perantara antara aktivitas dan beberapa konsekuensi yang terpisah seperti penghargaan secara lisan atau penghargaan yang berwujud (Gagne \& Deci, 2005). Misalnya, seseorang terlibat dalam suatu pekerjaan karena lebih merasa bertanggung jawab atas pekerjaan tersebut daripada sekedar tertarik dengannya karena adanya regulasi yang berlaku (Zhang, Zhang, Song, \& Gong, 2016).

Motivasi intrinsik sebagian besar dihapuskan oleh faktor-faktor seperti insentif moneter, penghargaan, kompetisi, tujuan, standar dan batas waktu (Locke \& Latham, 1990). Insentif moneter telah lama didiskusikan dari perspektif teori maupun praktis terkait dengan pengaruhnya terhadap motivasi karyawan dan kinerja (Jenkins, G. Douglas, Mitra, Gupta, \& Shaw, 1998). Insentif moneter juga merupakan ciri utama dari sistem pengendalian akuntansi (Stone, Bryant, \& Wier, 2010). Faktor yang mempengaruhi komitmen atas pencapaian tujuan di antaranya adalah insentif moneter, kemampuan, dan informasi terkait penugasan (Guymon, Balakrishnan, \& Tubbs, 2008). Penawaran insentif moneter atau finansial digunakan untuk meningkatkan kinerja karyawan (Bailey, Brown, \& Cocco, 1998). Sebagian besar karyawan bekerja untuk mendapatkan uang, sehingga penggunaan insentif moneter sebagai strategi utama dalam konteks motivasi (Gagne \& Deci, 2005). 
Aulia Azzardina | Pengaruh Motivasi, Kompleksitas Tugas, dan Insentif Moneter Terhadap Kinerja Individu

Ketika kebutuhan individu tidak tercapai, seseorang cenderung untuk mengadopsi motivasi ekstrinsik daripada hanya berfokus pada kepuasan atau mengutamakan motivasi intrinsiknya (Deci \& Ryan, 2008). Penelitian yang melibatkan keberadaan motivasi dalam pelaksanaan tugas telah banyak dilakukan (Deci \& Ryan, 2008; Kunz, 2015; Ryan \& Deci, 2000). Akan tetapi penelitian-penelitian sebelumnya belum melibatkan aspek kompleksitas tugas terkait dengan motivasi. Untuk itu, penelitian ini berfokus untuk mengetahui pengaruh motivasi terhadap kinerja dalam pengerjaan tugas yang kompleks. Jika penelitian-penelitian sebelumnya berfokus pada dikotomi insentif moneter berdasarkan individu (Cianci, Kaplan, \& Samuels, 2013; Presslee, Vance, \& Webb, 2013) dan kelompok (Naranjo-Gil, Cuevas-Rodríguez, LópezCabrales, \& Sánchez, 2012), skema piece-rate dan turnamen (Hannan, Khrisnan, \& Newman, 2008) serta goal contingent (Bailey dkk., 1998), penelitian ini memilih skema insentif moneter yang diinformasikan dan tidak diinformasikan. Kategorisasi ini didasarkan pada lingkungan kerja yang tidak selalu menyampaikan keberadaan insentif atas sebuah penugasan. Dengan demikian, pada penugasan tanpa disertai informasi keberadaan insentif akan didapati motivasi partisipan secara otentik, yaitu intrinsik atau ekstrinsik.

Penelitian ini bertujuan untuk mengetahui sedikitnya dua hal. Pertama, mengetahui bagaimana peran insentif moneter dalam penugasan yang kompleks. Kedua, mengetahui peran kedua skema insentif dalam hubungan antara motivasi dan kompleksitas tugas terhadap kinerja. Adanya insentif moneter membawa pada kinerja karyawan secara lebih baik ketika tingkat kesulitan ditentukan secara mandiri (Presslee dkk., 2013). Tugas dalam penelitian ini telah ditentukan melalui perlakuan dalam eksperimen dengan tidak memberi partisipan hak untuk memilih jenis tugas. Hal ini dilakukan untuk menghindari kerugian potensial, yang mana seseorang akan bersifat lebih risk-averse, sesuai dengan perilaku goal-setting terkait penghargaan berwujud, guna meraih tujuan yang lebih mudah dicapai (Presslee dkk., 2013). Perilaku ini kemudian mendorong seseorang untuk mencari faktor eksternal yang dapat meningkatkan motivasi mereka. Oleh karena itu, keberadaan insentif moneter diduga memoderasi hubungan antara motivasi dan kompleksitas tugas terhadap kinerja.

\section{TINJAUAN PUSTAKA}

Perbedaan antara motivasi intrinsik dan ekstrinsik bukan tentang sesuatu yang ada di luar atau di dalam tugas, melainkan sesuatu yang ada dalam diri seseorang (Locke \& Latham, 1990). Motivasi intrinsik menyebabkan seseorang melakukan aktivitas karena seseorang menganggap hal tersebut menarik dan mendatangkan kepuasan secara spontan (Gagne \& Deci, 2005). Kunz (2015) menemukan bahwa baik motivasi autonomous maupun controlled berhubungan positif dengan usaha. Seseorang dengan motivasi ekstrinsik memerlukan perantara antara aktivitas dan beberapa konsekuensi yang terpisah seperti penghargaan verbal atau penghargaan yang berwujud (Gagne \& Deci, 2005). Penelitian ini kemudian melibatkan keberadaan insentif moneter yang diinformasikan sebelum pengerjaan tugas dan insentif moneter yang tidak diinformasikan. Dalam hal ini, komitmen tujuan tercapai ketika kompensasi menjadi bagian dari pencapaian tujuan daripada ketika kompensasi tidak dilibatkan (Guymon dkk., 2008). Seseorang dengan motivasi intrinsik tidak memerlukan perantara seperti insentif moneter dalam penugasan.

Terkait dengan penetapan tujuan seseorang, goal setting theory telah dikembangkan selama lebih dari seperempat abad (Latham \& Pinder, 2005). Teori ini mengasumsikan bahwa tindakan seseorang diarahkan oleh tujuan dan niat (Locke \& Latham, 1990). Keputusan dalam lingkungan bisnis dapat melibatkan tugas penilaian seperti transaksi atau perubahan metode perhitungan persediaan (Buchheit, Dalton, Downen, \& Pippin, 2012). Tidak hanya itu, keputusan bisnis juga dibuat dalam penilaian berulang seperti keputusan jual atau beli, penggunaan material dan peramalan hasil di masa depan (Buchheit dkk., 2012). 
Aulia Azzardina | Pengaruh Motivasi, Kompleksitas Tugas, dan Insentif Moneter Terhadap Kinerja Individu

\section{Pengembangan Hipotesis}

Kunz (2015) menyatakan bahwa motivasi intrinsik datang dari kenyamanan atas tugas pada seseorang yang termotivasi secara intrinsik yang merasa terikat dengan tugas karena orang tersebut menyukainya. Sejalan dengan hal tersebut, Gagne dan Deci (2005) menyatakan bahwa motivasi intrinsik menyebabkan seseorang melakukan aktivitas karena menganggap bahwa hal tersebut menarik dan mendatangkan kepuasan secara spontan. Hal ini berbeda dengan motivasi ekstrinsik yang memerlukan perantara antara aktivitas dan beberapa konsekuensi yang terpisah seperti penghargaan secara lisan atau penghargaan yang berwujud (Gagne \& Deci, 2005). Maka, seseorang dengan motivasi intrinsik diduga akan memiliki kinerja yang lebih baik dibandingkan dengan seseorang dengan motivasi ekstrinsik ketika mereka dihadapkan dengan tugas yang sejalan dengan ketertarikan mereka. Untuk itu, hipotesis pertama dirumuskan sebagai berikut.

H1: Individu dengan motivasi intrinsik berkinerja lebih baik daripada individu dengan motivasi ekstrinsik.

Target merupakan komponen integral dari sistem pengendalian manajemen dan memainkan peran yang signifikan dalam pencapaian hasil kinerja yang diinginkan (Ioannou, Li, \& Serafeim, 2016). Bagian terbesar dari penelitian tentang tujuan sebagai alat prediksi telah dilakukan dalam task goal theory (Klein, Wesson, Hollenbeck, \& Alge, 1999). Locke dan Latham (1990) menggunakan istilah - goal berkenaan dengan tujuan yang diharapkan dalam hal tingkat kinerja yang akan dicapai pada tugas. Peningkatan usaha yang secara langsung mengarah pada kinerja bisa datang dalam wujud peningkatan intensitas usaha tentang perhatian individu terhadap suatu tugas dalam durasi tertentu (Bonner \& Sprinkle, 2002). Tujuan yang lebih sulit biasanya membawa pada usaha yang lebih besar, tetapi menghasilkan skor kinerja yang lebih rendah daripada tugas yang lebih mudah (Locke \& Latham, 1990). Berdasarkan rasionalisasi tersebut, tersusun hipotesis sebagai berikut.

H2: Individu menunjukkan kinerja lebih baik saat dihadapkan pada tugas dengan tingkat kompleksitas yang lebih rendah daripada tingkat kompleksitas tugas yang tinggi.

Secara teori, selama expected benefit yang disediakan oleh insentif moneter lebih besar daripada biaya pengerjaan tugas, maka insentif moneter terikat dengan kinerja dalam menimbulkan usaha yang diarahkan (Bonner \& Sprinkle, 2002). Berdasarkan teori, insentif moneter memiliki pengaruh positif terhadap intensitas usaha jika individu meyakini bahwa peningkatan sumber daya kognitif jangka pendek mengakibatkan peningkatan kinerja sehingga menghasilkan penghargaan (Bonner \& Sprinkle 2002). Keberadaan insentif moneter bagi motivasi ekstrinsik merupakan suatu dukungan, sedangkan insentif moneter dapat merusak motivasi intrinsik. Untuk itu, individu yang memiliki informasi insentif moneter akan menunjukkan kinerja yang lebih baik dibandingkan dengan individu tanpa informasi insentif moneter. Khususnya bagi individu dengan motivasi ekstrinsik. Maka dari itu, hipotesis ketiga dirumuskan sebagai berikut.

H3: Ketika diberi informasi insentif moneter, individu dengan motivasi ekstrinsik berkinerja lebih baik daripada individu dengan motivasi intrinsik.

Penetapan tujuan adalah komponen penting dari sistem pengendalian pada banyak organisasi (Kelly, Webb, \& Vance, 2015) dan memainkan peran yang signifikan dalam pencapaian hasil kinerja yang diinginkan (Ioannou dkk., 2016). Perusahaan sering menetapkan tugas yang sulit untuk memotivasi para karyawan (Kelly dkk., 2015). Goal setting theory menyatakan bahwa representasi tujuan seseorang yang merupakan penyebab yang efisien dari perilaku dan kinerja seseorang akan dimaksimalkan ketika mereka secara spesifik menetapkan tujuan yang sulit dan memahami perilaku apa yang akan membawa pada tujuan dan perasaan kompeten untuk berperilaku demikian (Gagne \& Deci, 2005). Penelitian ini tidak dilakukan dengan memanipulasi adanya tujuan jangka panjang. Untuk itu, diduga individu dengan informasi insentif moneter akan 
Aulia Azzardina | Pengaruh Motivasi, Kompleksitas Tugas, dan Insentif Moneter Terhadap Kinerja Individu

menunjukkan kinerja yang lebih baik daripada individu tanpa informasi insentif moneter ketika dihadapkan pada kedua tingkat kompleksitas. Hal ini disebabkan oleh iklim kompetitif yang ada. Berdasar pada rasionalisasi tersebut, maka tersusun hipotesis sebagai berikut.

H4: Individu dengan informasi insentif moneter berkinerja yang lebih baik daripada individu tanpa informasi insentif moneter ketika dihadapkan pada kedua jenis kompleksitas tugas.

Lingkungan dengan beberapa tugas merupakan lingkungan di mana individu mengalokasikan usaha, baik lintas dimensi dalam penugasan tunggal atau beberapa tugas dalam satu deskripsi pekerjaan (Lynn Hannan, McPhee, Newman, \& Tafkov, 2013). Meskipun secara umum motivasi menguntungkan kinerja, namun perubahan usaha dapat menurunkan kinerja (Lynn Hannan dkk., 2013). Dalam penelitian ini, partisipan dengan motivasi ekstrinsik diasumsikan memiliki komitmen yang lebih rendah daripada partisipan dengan motivasi intrinsik. Ketika setiap individu memiliki kesulitan tujuan yang sama, individu dengan komitmen yang lebih tinggi terhadap tujuan akan lebih baik daripada individu dengan komitmen lebih rendah (Klein dkk., 1999). Maka dari itu, hipotesis kelima disusun sebagai berikut.

H5: Individu dengan motivasi intrinsik memiliki kinerja yang lebih baik daripada individu dengan motivasi ekstrinsik dalam menghadapi tugas dengan kompleksitas tugas rendah.

Individu yang pernah gagal mendapatkan bonus pada periode kerja sebelumnya terbukti menetapkan tujuan yang kurang menantang (Webb dkk., 2010). Saat terdapat insentif atas capaian yang diraih, individu merasa bertanggungjawab untuk mencurahkan usaha yang memadai demi mencapai tujuan tersebut (Kelly dkk., 2015). Individu dengan motivasi ekstrinsik diduga meningkatkan usaha mereka setelah mengetahui keberadaan insentif moneter. Individu tersebut diduga juga menghadapi kesulitan tugas dengan lebih baik dibandingkan dengan individu yang memiliki motivasi intrinsik saat keberadaan insentif moneter tidak diinformasikan. Maka dari itu, hipotesis keenam disusun sebagai berikut.

H6: Individu dengan motivasi ekstrinsik dan informasi insentif moneter berkinerja lebih baik daripada individu tanpa informasi insentif moneter ketika dihadapkan pada tugas dengan kompleksitas tinggi.

\section{METODE PENELITIAN}

Penelitian ini menggunakan metode eksperimen semu dengan desain penelitian 2x2 between-subject. Metode eksperimen digunakan untuk menginvestigasi suatu fenomena melalui rekayasa keadaan atau kondisi dengan memberlakukan prosedur tertentu yang kemudian hasil dari perekayasaan tersebut diamati dan diinterpretasikan (Nahartyo, 2013). Eksperimen semu atau quasi-experiment digunakan dalam penelitian ini karena peneliti tidak memanipulasi salah satu variabel independen, yaitu motivasi.

Subjek penelitian yang dilibatkan dalam eksperimen ini adalah mahasiswa jurusan akuntansi yang tengah menempuh studi pada semester empat dan lima di jenjang sarjana di Fakultas Ekonomika dan Bisnis salah satu universitas negeri di Yogyakarta. Untuk memenuhi kebutuhan partisipan pada delapan sel, penelitian melibatkan 80 orang partisipan. Partisipan diharuskan lulus dari matakuliah Akuntansi Keuangan Menengah 1 untuk menjadi partisipan karena salah satu penugasan melibatkan soal akuntansi. Penempatan partisipan dalam setiap sel melibatkan randomisasi untuk menghindari bias dan memperoleh heterogenitas pada masing masing sel. Penelitian ini menggunakan two-way dan three-way ANOVA between-subject dalam analisis statistik.

Partisipan mengerjakan beberapa soal hitungan sederhana dengan terlebih dahulu melakukan konversi huruf ke dalam angka lalu angka ke dalam angka lain pada setiap butir soal. Pada masing-masing kategori, partisipan diberi waktu selama 30 detik. 
Aulia Azzardina | Pengaruh Motivasi, Kompleksitas Tugas, dan Insentif Moneter Terhadap Kinerja Individu

Setelah mengerjakan soal, partisipan akan diminta untuk mengisi kuesioner Intrinsic Motivation Inventory (IMI). Setelah selesai mengisi kuesioner, partisipan diminta untuk menghitung sendiri jumlah skor pada instrumen IMI. Pengelompokan partisipan berdasarkan motivasi dilakukan dengan melakukan median-split setelah kelas eksperimen selesai. Selanjutnya, partisipan memulai pengerjaan tugas dengan waktu yang telah ditentukan. Partisipan terbagi ke dalam dua kelompok secara acak, yaitu kelompok dengan informasi insentif moneter dan tanpa informasi insentif moneter. Masing masing kelompok dihadapkan pada dua kategori kompleksitas tugas, yaitu tinggi dan rendah. Setiap partisipan memiliki durasi yang sama untuk pengerjaan setiap tugas. Tugas dikemas di dalam amplop yang sama. Pada kedua tipe kelompok insentif, cek manipulasi akan dilakukan satu kali. Partisipan juga diminta mengisi berapa jumlah insentif moneter yang mereka dapatkan jika mampu menjawab sejumlah soal dengan benar.

\section{HASIL DAN PEMBAHASAN}

Data demografi dijelaskan dalam Tabel 1.

Tabel 1. Data Demografi

\begin{tabular}{|c|c|c|c|}
\hline \multicolumn{2}{|c|}{ Keterangan } & Jumlah & Persentase \\
\hline \multirow{2}{*}{ Jenis Kelamin } & Laki-laki & 20 & $30,3 \%$ \\
\hline & Perempuan & 46 & $60,7 \%$ \\
\hline \multirow{7}{*}{$\begin{array}{c}\text { Nilai Matakuliah } \\
\text { Akuntansi Keuangan } \\
\text { Menengah I }\end{array}$} & A & 16 & $24,24 \%$ \\
\hline & A- & 7 & $10,6 \%$ \\
\hline & $\mathrm{B}+$ & 9 & $13,6 \%$ \\
\hline & B & 18 & $27,27 \%$ \\
\hline & B- & 1 & $1,51 \%$ \\
\hline & $\mathrm{C}+$ & 2 & 3,03\% \\
\hline & C & 3 & $4,54 \%$ \\
\hline \multirow[t]{3}{*}{ Semester } & 4 & 9 & $13,6 \%$ \\
\hline & 6 & 44 & $66,7 \%$ \\
\hline & 8 & 9 & $66,7 \%$ \\
\hline
\end{tabular}

Sebanyak 66 partisipan dapat digunakan datanya pada penelitian ini. Sebanyak 20 partisipan (30,3\%) berjenis kelamin laki-laki dan sebanyak 46 partisipan $(69,7 \%)$ berjenis kelamin perempuan. Sebanyak 9 orang partisipan (13,6\%) merupakan mahasiswa yang tengah menempuh studi pada semester keempat, 44 partisipan $(66,7 \%)$ pada semester keenam dan 9 (13,6\%) orang pada semester kedelapan. Sisanya, sebanyak 4 orang $(6,1 \%)$ tidak mengisi informasi semester. Para partisipan dipastikan telah menempuh matakuliah Akuntansi Keuangan Menengah I. Sebanyak 16 orang $(24,24 \%)$ mendapatkan nilai A, 7 orang $(10,6)$ mendapatkan nilai A-, 9 orang $(13,6 \%)$ mendapatkan nilai B+ dan 18 orang $(27,27 \%)$ mendapatkan nilai B dalam matakuliah tersebut, sedangkan 6 orang $(9,09)$ lainnya memperoleh nilai di bawah B dan 10 orang lainnya $(15,15)$ tidak mengisi informasi tersebut atau menyatakan lupa.

\section{Pengujian Randomisasi}

Hasil uji randomisasi Chi-Square ditunjukkan pada Tabel 2.

Tabel 2. Hasil Uji Randomisasi Chi-Square

\begin{tabular}{lll}
\hline Karakteristik & Pearson Chi-Square & Sig. \\
\hline Jenis Kelamin & 3,800 & 0,284 \\
Nilai Matakuliah & 24,160 & 0,150 \\
Semester & 3,267 & 0,775 \\
\hline
\end{tabular}


Aulia Azzardina | Pengaruh Motivasi, Kompleksitas Tugas, dan Insentif Moneter Terhadap Kinerja Individu

Tabel 2 menunjukkan bahwa tujuan randomisasi telah tecapai dengan baik. Tampak bahwa seluruh nilai pada kolom Pearson Chi-Square untuk ketiga kategori berada di atas 0,05 . Artinya, tidak terdapat perbedaan yang signifikan antara masing-masing kelompok baik dari jenis kelamin (Chi-square $=3,800, \mathrm{p}>0,284$ ), nilai matakuliah (Chi-square $=$ 24,160, $\mathrm{p}>0,150$ ) dan semester yang tengah ditempuh para partisipan (Chi-square $=$ $3,267, \mathrm{p}>0,775)$. Berdasarkan hasil tersebut, maka dapat disimpulkan bahwa keberadaan jenis kelamin, nilai matakuliah dan semester yang berbeda-beda tidak mempengaruhi hasil eksperimen yang telah dilakukan.

\section{Pengujian Pengaruh Karakteristik Demografi terhadap Variabel Dependen}

Pengujian berikutnya yang perlu dilakukan adalah pengujian untuk mengetahui adanya pengaruh karakteristik demografi terhadap variabel dependen. Pengujian ini dilakukan guna mengetahui ada atau tidaknya pengaruh dari karakteristik subjek terhadap partisipan selama dalam proses eksperimen. Pengujian ini dilakukan dengan menggunakan one-way ANOVA. Hasil dari pengujian tersebut terangkum dalam Tabel 3.

Tabel 3. Hasil Uji Karakteristik Subjek One-way ANOVA

\begin{tabular}{lcccc}
\hline \multirow{2}{*}{ Karakteristik Subjek } & \multicolumn{3}{c}{ Kinerja } \\
\cline { 2 - 5 } & df & F-Statistik & Sig. & Levene's Test \\
\hline Jenis Kelamin & 1 & 1,687 & 0,199 & 0,806 \\
Nilai Matakuliah & 6 & 0,589 & 0,737 & 0,428 \\
Semester & 2 & 2,200 & 0,120 & 0,056 \\
\hline
\end{tabular}

Berdasarkan hasil yang tersaji pada Tabel 3 dapat diketahui bahwa tidak terdapat karakteristik subjek yang memengaruhi perilaku para subjek eksperimen dalam menunjukkan kinerja mereka. Hal ini tampak dari nilai signifikansi masing-masing karakteristik yakni jenis kelamin $(\mathrm{p}<0,199)$, nilai matakuliah Akuntansi Keuangan Menengah I $(\mathrm{p}<0,737)$ dan pada semester berapakah mereka menempuh studi ketika berpartisipasi sebagai subjek eksperimen $(\mathrm{p}<0,120)$.

\section{Pengujian Hipotesis}

Partisipan terbagi ke dalam empat sel eksperimen yang masing-masing diperlakukan secara berbeda. Berikut adalah ringkasan tampilan perlakuan eksperimen dalam bentuk tabel beserta hasil pengujian statistiknya. Pengujian hipotesis ini ditujukan untuk membuktikan hipotesis main effect, simple effect dan interaction effect. Seluruh hipotesis diuji dengan menggunakan Analysis of Variance (ANOVA). Terdapat beberapa asumsi yang harus terlebih dahulu dipenuhi sebelum melakukan pengujian ini. Pengujian homogenitas dilakukan dengan menggunakan Levene's Test. Hasil dari pengujian tersebut ditampilkan dalam Tabel 4.

Tabel 4. Hasil Levene's Test

\begin{tabular}{ccccc}
\hline F & df1 & df2 & Sig. \\
\hline 3.738 & 7 & 58 & 0,002 \\
\hline
\end{tabular}

Berdasarkan pengujian Levene's Test tampak bahwa tingkat signifikansinya sebesar 0,002 yang lebih kecil daripada 0,05. Artinya, varians dari kelompok partisipan memiliki perbedaan yang signifikan atau tidak homogen. Akan tetapi, berdasarkan pengujian untuk mengetahui asumsi lain yakni normalitas. Pengujian dengan menggunakan One-Sample Kolmogorov-Smirnov Test menunjukkan bahwa asumsi normalitas terpenuhi pada nilai signifikansi sebesar 0,721>0,05. Hasil tersebut ditampilkan pada Tabel 5. Terpenuhinya asumsi tersebut mendukung penggunaan ANOVA dalam penelitian ini. 
Aulia Azzardina | Pengaruh Motivasi, Kompleksitas Tugas, dan Insentif Moneter Terhadap Kinerja Individu

Tabel 5. One-Sample Kolmogorov-Smirnov Test

\begin{tabular}{lc}
\hline \multicolumn{1}{c}{ Keterangan } & Residual for $K$ \\
\hline Kolmogorov-Smirnov Z & 0,694 \\
Asymp. Sig. (2-tailed) & 0,721 \\
\hline
\end{tabular}

Tabel 6. ANOVA

\begin{tabular}{llll}
\hline Keterangan & df & F-statistik & Sig. \\
\hline $\mathrm{M} * \mathrm{I}$ & 1 & 1,196 & 0,279 \\
$\mathrm{I} * \mathrm{KT}$ & 1 & 0,383 & 0,538 \\
$\mathrm{M} * \mathrm{I} * \mathrm{KT}$ & 1 & 2,393 & 0,127 \\
$\mathrm{M}$ & 1 & 3,167 & 0,080 \\
$\mathrm{KT}$ & 1 & 103,859 & 0,000 \\
$\mathrm{R}$ Squared $=0,664$ (Adjusted R Squared $=0,624)$ & \\
\hline
\end{tabular}

Individu dengan motivasi intrinsik diduga berkinerja lebih baik daripada individu dengan motivasi ekstrinsik (H1). Hasil pengujian pada Tabel 6 menunjukkan bahwa motivasi berpengaruh signifikan terhadap kinerja dengan angka signifikansi $0,080<0,10$. Tabel 6 menunjukkan perbandingan rata-rata antar grup. Pada kelompok partisipan dengan motivasi intrinsik, sebanyak tiga dari 4 kelompok memiliki rata-rata lebih tinggi daripada kelompok dengan motivasi ekstrinsik. Akan tetapi, tampak pada Tabel 7 bahwa total rata-rata pada kelompok intrinsik lebih besar daripada kelompok ekstrinsik. Dengan demikian, hipotesis pertama terdukung.

Tabel 7. Total Rata-rata Motivasi

\begin{tabular}{ll}
\hline Motivasi & $\begin{array}{l}\text { Total rata-rata } \\
\text { (Std. Deviasi) }\end{array}$ \\
\hline Ekstrinsik & 35,0606 \\
& $(18,04887)$ \\
Intrinsik & 40,6364 \\
& $(21,03281)$ \\
\hline
\end{tabular}

Tabel 8. Total Rata-rata Kompleksitas Tugas

\begin{tabular}{ll}
\hline Kompleksitas Tugas & $\begin{array}{l}\text { Rata-rata } \\
\text { (Standar deviasi) }\end{array}$ \\
\hline Rendah & 54,0323 \\
& $(16,18998)$ \\
Tinggi & 23,5143 \\
& $(7,51321)$ \\
Total & 37,8485 \\
& $(19,64825)$ \\
\hline
\end{tabular}

Individu berkinerja lebih baik saat dihadapkan pada tingkat kompleksitas tugas yang rendah daripada ketika dihadapkan pada tugas dengan kompleksitas tinggi (H2). Berdasarkan pengujian dengan ANOVA yang tampak pada Tabel 6, kompleksitas tugas berpengaruh secara signifikan terhadap kinerja pada level 0,01 yakni sebesar 0,000. Berdasarkan Tabel 8, kelompok yang dihadapkan pada tugas dengan kategori kompleksitas tinggi menunjukkan kinerja yang lebih rendah daripada kelompok dengan kompleksitas tugas rendah.

Pengaruh motivasi terhadap kinerja terdukung secara statistik pada level $0,080<0,10$. Akan tetapi, berdasarkan Tabel 9 tampak bahwa total rata-rata kelompok dengan motivasi intrinsik lebih besar daripada kelompok dengan motivasi ekstrinsik $(42,4118>32,8056)$. Artinya, hipotesis ketiga tidak terdukung karena kelompok dengan 
Aulia Azzardina | Pengaruh Motivasi, Kompleksitas Tugas, dan Insentif Moneter Terhadap Kinerja Individu

motivasi intrinsik menunjukkan kinerja yang lebih baik ketika mereka mengetahui tentang keberadaan insentif moneter.

Tabel 9. Total Rata-rata Insentif Moneter Diinformasikan

\begin{tabular}{lll}
\hline Motivasi & $\begin{array}{l}\text { Insentif } \\
\text { moneter }\end{array}$ & $\begin{array}{l}\text { Rata-rata } \\
\text { (Standar deviasi) }\end{array}$ \\
\hline Ekstrinsik & Diinformasikan & 32,8056 \\
& & $(13,57890)$ \\
Intrinsik & Diinformasikan & 42,4118 \\
& & $(22,76115)$ \\
\hline
\end{tabular}

Hasil pengujian menggunakan ANOVA menunjukkan nilai signifikansi 0,538 yang lebih besar daripada 0,1. Hasil ini menunjukkan bahwa tidak terdapat interaksi antara variabel kompleksitas tugas, insentif moneter dan kinerja. Artinya, hipotesis keempat tidak terdukung. Untuk itu, tidak dilakukan analisis pada tabel deskriptif.

Individu dengan motivasi intrinsik diduga berkinerja lebih baik daripada individu dengan motivasi ekstrinsik dalam menghadapi tugas dengan kompleksitas tugas rendah tanpa informasi insentif moneter (H5). Melalui Tabel 6 dapat diketahui bahwa interaksi antara motivasi, kompleksitas tugas, insentif moneter dan kinerja tidak signifikan pada nilai 0,127>0,1 dengan F-statistik 0,2393. Artinya, tidak terdapat dukungan untuk threeway interaction ini. Hipotesis keenam menduga bahwa individu dengan motivasi ekstrinsik dan informasi insentif moneter berkinerja lebih baik daripada individu tanpa informasi insentif moneter ketika dihadapkan pada tugas dengan kompleksitas tinggi. Hipotesis ini juga tidak terdukung pada nilai 0,127>0,1 dengan F-statistik 0,2393. Untuk itu, tidak dilakukan pembahasan lanjutan tentang bagaimana perbandingan kinerja antar sel yang terkait.

\section{Pembahasan}

Pengujian hipotesis yang telah dilakukan menghasilkan beberapa hipotesis yang terdukung. Kedua hipotesis main effect, yakni hipotesis pertama dan kedua memperoleh dukungan secara signifikan. Akan tetapi empat hipotesis lainnya tidak terdukung. Keempat hipotesis tersebut terdiri dari dua hipotesis simple effect dan dua hipotesis interaction effect. Penelitian ini menunjukkan bahwa individu akan menunjukkan kinerja yang lebih baik saat dihadapkan pada tingkat kompleksitas tugas yang rendah daripada ketika dihadapkan pada tugas dengan kompleksitas tinggi. Hal ini terjadi karena tugas dengan kompleksitas yang lebih rendah relatif lebih mudah dicapai, sejalan dengan bias heuristik (Kahneman, 2012). Situasi yang kompleks sering kali cenderung dinamis dan mendorong seseorang untuk bertindak dengan cepat dalam waktu yang terbatas (Eseryel, Law, Ifenthaler, Ge, \& Miller, 2013). Untuk itu, pada tugas yang kurang kompleks, partisipan memerlukan usaha yang relatif lebih kecil dengan kemampuan berfokus yang cenderung stabil. Hasilnya, partisipan dapat menunjukkan kinerja yang lebih baik.

Berbeda dengan dua hipotesis pertama, hipotesis ketiga dan keempat tidak terdukung dan hal ini mengindikasikan bahwa insentif gagal merusak motivasi intrinsik. Kegagalan ini diduga terjadi karena individu dengan motivasi intrinsik memiliki keinginan yang lebih kuat daripada individu dengan motivasi ekstrinsik. Para pemberi kerja mencoba meningkatkan motivasi intrinsik karyawan dengan memberikan upah dasar yang kompetitif dan insentif untuk meningkatkan motivasi ekstrinsik (Kuvaas, Buch, Weibel, Dysvik, \& Nerstad, 2017). Akibatnya, mereka berusaha yang lebih besar baik ketika mereka menerima informasi insentif maupun tidak. Usaha tersebut yang kemudian linier dengan hasil pekerjaan mereka, terutama bagi partisipan dengan motivasi intrinsik.

Sementara itu, hipotesis kelima menduga individu dengan motivasi intrinsik berkinerja lebih baik daripada individu dengan motivasi ekstrinsik dalam menghadapi tugas dengan kompleksitas rendah tanpa informasi insentif moneter. Hipotesis ini tidak 
Aulia Azzardina | Pengaruh Motivasi, Kompleksitas Tugas, dan Insentif Moneter Terhadap Kinerja Individu

terdukung, tetapi terdapat perbedaan rata-rata yang signifikan pada kinerja mereka. Tidak terdukungnya hipotesis ini diduga terjadi karena keberadaan insentif tidak mampu memengaruhi para partisipan. Dampak positif dari penetapan tujuan tidak hanya berlaku jika tujuan dipilih oleh seseorang, melainkan juga saat tujuan ditetapkan oleh atasan (Goerg \& Kube, 2012). Lebih lajut, Goerg dan Kube (2012) menemukan bahwa dampak positif dari tujuan yang ditetapkan oleh diri sendiri tetap menonjol meski tanpa adanya insentif moneter. Penelitian ini menduga insentif moneter yang ditawarkan tidak cukup signifikan bagi partisipan, sehingga partisipan dengan motivasi intrinsik berkinerja lebih baik daripada partisipan dengan motivasi ekstrinsik dalam penugasan. Temuan ini memberikan justifikasi terhadap peran motivasi intrinsik, meski belum mendukung peran insentif bagi individu dengan motivasi ekstrinsik.

\section{SIMPULAN, KETERBATASAN, DAN SARAN}

Berdasarkan hasil eksperimen semu yang dilakukan, dapat disimpulkan bahwa secara umum motivasi dan kompleksitas tugas berpengaruh terhadap kinerja. Akan tetapi, keberadaan insentif yang diduga memoderasi hubungan dari ketiga variabel tersebut tidak terbukti memiliki pengaruh moderasi dalam hubungan. Individu yang memiliki motivasi intrinsik menunjukkan bahwa kinerja mereka lebih baik daripada individu yang berada dalam kelompok dengan motivasi ekstrinsik. Sementara itu, keberadaan kompleksitas tugas yang berbeda juga menghasilkan kinerja yang berbeda dari para partisipan. Individu yang dihadapkan pada kompleksitas tugas yang rendah secara signifikan menunjukkan perbedaan rata-rata kinerja yang lebih tinggi. Secara umum, individu dengan motivasi intrinsik menunjukkan kinerja yang lebih baik daripada individu dengan motivasi ekstrinsik baik ketika individu memiliki informasi keberadaan insentif maupun tanpa insentif. Setiap kelompok yang dihadapkan pada kompleksitas soal yang tinggi memiliki rata-rata kinerja yang lebih rendah daripada kelompok yang dihadapkan pada kompleksitas tugas yang rendah. Hal ini diduga disebabkan oleh adanya bias kompetensi. Untuk itu, insentif moneter diduga gagal memoderasi karena bias kompetensi ini sulit untuk dihindari oleh partisipan. Untuk interaksi tiga arah yang melibatkan keempat variabel, ditemukan hasil tidak terdapat pengaruh. Hal ini terjadi diduga karena kuatnya motivasi para partisipan dengan motivasi intrinsik dan adanya bias kompetensi para partisipan. Insentif moneter kemudian tidak mampu mempengaruhi hubungan tersebut.

Penelitian ini memiliki beberapa keterbatasan. Pertama, terdapat dugaan adanya bias kompetensi partisipan. Penelitian ini telah melibatkan simulasi singkat tentang pengerjaan tugas hitungan matematis dengan melibatkan penugasan yang serupa dengan penugasan sebenarnya. Akan tetapi, pada penugasan riil, di mana partisipan diminta mengerjakan tugas dengan soal akuntansi keuangan, partisipan diharuskan untuk melibatkan konsep akuntansi keuangan pada penugasan tersebut. Pada penugasan ini, diduga terdapat bias kompetensi pada partisipan. Kedua, cek manipulasi yang termasuk dalam kategori gagal pada penelitian disebabkan oleh tidak terisinya lembar cek manipulasi, yang mungkin terjadi karena pengaturan lembar eksperimen yang diberikan memungkinkan partisipan untuk melewatkan pengisian. Selain itu, beberapa cek manipulasi untuk skema insentif tidak sesuai dengan sel eksperimen di mana partisipan ditempatkan. Hal ini diduga terjadi akibat adanya insentif moneter maupun non-moneter yang diberikan pasca pengambilan data penelitian-penelitian sebelumnya. Pengalaman partisipan pada penelitian sebelumnya memungkinkan untuk membuat mereka berekspektasi atas adanya penghargaan pasca pengambilan data. Ketiga, penelitian ini belum melibatkan aspek kompetisi dengan menciptakan atmosfer yang kompetitif dalam eksperimen. Kompetisi merupakan salah satu faktor yang dapat mempengaruhi kinerja individu. Keempat, partisipan dimungkinkan memiliki perspektif yang berbeda tentang besaran nilai suatu insentif moneter. Penelitian ini belum dilengkapi dengan survei awal tentang persepsi individu terhadap sejumlah insentif. 
Aulia Azzardina | Pengaruh Motivasi, Kompleksitas Tugas, dan Insentif Moneter Terhadap Kinerja Individu

Penelitian selanjutnya dapat mempertimbangkan untuk memberi partisipan pelatihan awal yang terkait dengan keperluan pengerjaan tugas untuk mengurangi bias kompetisi karena diharapkan memori partisipan akan terbarukan. Selain itu, eksperimenter dapat mendesain pelaksanaan eskperimen dengan mekanisme lain yang dapat mendukung kepastian lembar cek manipulasi terisi dengan baik, sehingga hasil kerja partisipan dapat dilibatkan sebagai data penelitian. Dalam penelitian ini, partisipan berkompetisi dengan diri mereka sendiri, penelitian berikutnya dapat melibatkan variabel kompetisi dengan partisipan lain untuk mengukur kinerja partisipan. Hal ini dapat lebih representatif dalam mengukur kinerja di individu di organisasi yang skema insentifnya melibatkan faktor kompetisi. Selain itu, penelitian berikutnya dapat melibatkan variabel urgensi atau prioritas tugas (Bayuk \& Patrick, 2021) untuk melibatkan otonomi partisipan dalam pemilihan tugas, di mana banyak lingkungan kerja memiliki pengaturan demikian. Penelitian berikutnya dapat dilakukan melalui eksperimen lapangan dirasa dapat merepresentasikan situasi sebenarnya secara lebih baik.

\section{DAFTAR PUSTAKA}

Bailey, C. D., Brown, L. D., \& Cocco, A. F. (1998). The Effects of Monetary Incentives on Worker Learning and Performance in an Assembly Task. Journal of Management Accounting Research, 10(3), 119-131. https://ssrn.com/abstract=117850

Bayuk, J. B., \& Patrick, V. M. (2021). Is the uphill road the one more taken? How task complexity prompts action on non-pressing tasks. Journal of Business Research, 128(January 2019), 436-449. https://doi.org/10.1016/j.jbusres.2021.02.012

Bonner, S. E., \& Sprinkle, G. B. (2002). The effects of monetary incentives on effort and task performance: Theories, evidence, and a framework for research. Accounting, Organizations and Society, 27(4-5), 303-345. https://doi.org/10.1016/S03613682(01)00052-6

Buchheit, S., Dalton, D., Downen, T., \& Pippin, S. (2012). Outcome feedback, incentives, and performance: Evidence from a relatively complex forecasting task. Behavioral Research in Accounting, 24(2), 1-20. https://doi.org/10.2308/bria-50151

Cianci, A. M., Kaplan, S. E., \& Samuels, J. A. (2013). The moderating effects of the incentive system and performance measure on managers' and their superiors' expectations about the manager's effort. Behavioral Research in Accounting, 25(1), 115-134. https://doi.org/10.2308/bria-50290

Deci, E. L., \& Ryan, R. M. (2008). Self-determination theory: A macrotheory of human motivation, development, and health. Canadian Psychology, 49(3), 182-185. https://doi.org/10.1037/a0012801

Eseryel, D., Law, V., Ifenthaler, D., Ge, X., \& Miller, R. (2013). An investigation of the interrelationships between motivation, engagement, and complex problem solving in game-based learning. Educational Technology and Society, 17(1), 42-53. https://www.jstor.org/stable/jeductechsoci.17.1.42

Gagne, M., \& Deci, E. L. (2005). Self-Determination Theory and Work Motivation. Journal of Organizational Behavior, 26(4), 331-362. https://doi.org/10.1002/job.322

Goerg, S. J., \& Kube, S. (2012). Goals (Th)at Work - Goals, Monetary Incentives, and Workers' Performance. Preprints of the Max Planck Institute for Research on Collective Goods. https://doi.org/10.2139/ssrn.2159663

Guymon, R. N., Balakrishnan, R., \& Tubbs, R. M. (2008). The Effect of Task Interdependence and Type of Incentive Contract on Group Performance. Journal of Management Accounting Research, 20(s1), 1-18. https://doi.org/10.2308/jmar.2008.20.s-1.1

Hannan, R., Khrisnan, R., \& Newman, A. H. (2008). The Effects of Disseminating Relative Performance Feedback in Tournament and Individual Performance Compensation Plans. Accounting Review, 83(4), 893-913. https://www.jstor.org/stable/30243529

Ioannou, I., Li, S. X., \& Serafeim, G. (2016). The effect of target difficulty on target completion: The case of reducing carbon emissions. Accounting Review, 91(5), 
Aulia Azzardina | Pengaruh Motivasi, Kompleksitas Tugas, dan Insentif Moneter Terhadap Kinerja Individu

1467-1492. https://doi.org/10.2308/accr-51307

Jenkins, G. Douglas, J., Mitra, A., Gupta, N., \& Shaw, J. D. (1998). Are financial incentives related to performance? A meta-analytic review of empirical research. Journal of Applied Psychology, 83(5), 777-787. https://doi.org/10.1037/0021-9010.83.5.777

Kahneman, D. (2012). Thinking, Fast and Slow. Penguin.

Kelly, K. O., Webb, R. A., \& Vance, T. (2015). The interactive effects of ex post goal adjustment and goal difficulty on performance. Journal of Management Accounting Research, 27(1), 1-25. https://doi.org/10.2308/jmar-50729

Klein, H. J., Wesson, M. J., Hollenbeck, J. R., \& Alge, B. J. (1999). Goal Commitment and the Goal Setting Process Conceptual Clarification and Emprical Synthesis. Journal of Applied Psychology, 84, 885-896. https://doi.org/10.1037/0021-9010.84.6.885

Kunz, J. (2015). Objectivity and subjectivity in performance evaluation and autonomous motivation: An exploratory study. Management Accounting Research, 27, 27-46. https://doi.org/10.1016/j.mar.2015.01.003

Kuvaas, B., Buch, R., Weibel, A., Dysvik, A., \& Nerstad, C. G. L. (2017). Do intrinsic and extrinsic motivation relate differently to employee outcomes? Journal of Economic Psychology, 61, 244-258. https://doi.org/10.1016/j.joep.2017.05.004

Latham, G. P., \& Pinder, C. C. (2005). Work Motivation Theory and Research at the Dawn of the Twenty-First Century. Annual Review of Psychology, 56(1), 485-516. https://doi.org/10.1146/annurev.psych.55.090902.142105

Locke, E. A., \& Latham, G. P. (1990). A Theory of Goal Setting \& Task Performance. Prentice-Hall, Inc. Retrieved from http://web.mit.edu/curhan/www/docs/Articles/15341_Readings/Motivation/Lock e Theory of Goal Setting Ch 1-2.pdf

Lynn Hannan, R., McPhee, G. P., Newman, A. H., \& Tafkov, I. D. (2013). The effect of relative performance information on performance and effort allocation in a multitask environment. Accounting Review, 88(2), 553-575. https://doi.org/10.2308/accr-50312

Nahartyo, E. (2013). Desain dan Implementasi Riset Eksperimen. UPP STIM YKPN.

Naranjo-Gil, D., Cuevas-Rodríguez, G., López-Cabrales, Á., \& Sánchez, J. M. (2012). The effects of incentive system and cognitive orientation on teams' performance. Behavioral Research in Accounting, 24(2), 177-191. https://doi.org/10.2308/bria50098

Presslee, A., Vance, T. W., \& Webb, R. A. (2013). The effects of reward type on employee goal setting, goal commitment, and performance. Accounting Review, 88(5), 18051831. https://doi.org/10.2308/accr-50480

Ryan, R., \& Deci, E. (2000). Self-determination theory and the facilitation of intrinsic motivation, social development, and well-being. The American Psychologist, 55(1), 68-78. https://doi.org/10.1037/0003-066X.55.1.68

Stone, D. N., Bryant, S. M., \& Wier, B. (2010). Why are financial incentive effects unreliable? An extension of self-determination theory. Behavioral Research in Accounting, 22(2), 105-132. https://doi.org/10.2308/bria.2010.22.2.105

Webb, A., Jeffrey, S. A., Schulz, A., Berberich, G., Bruggen, A., Kelly, K., Luft, J. (2010). Factors Affecting Goal Difficulty and Performance When Employees Select Their Own Performance Goals: Evidence from the Field. Journal of Management Accounting Research, 22221(209), 209-232. https://doi.org/10.2308/jmar.2010.22.1.209

Zhang, J., Zhang, Y., Song, Y., \& Gong, Z. (2016). The different relations of extrinsic, introjected, identified regulation and intrinsic motivation on employees' performance: Empirical studies following self-determination theory. Management Decision, Vol. 54 No, 2393-2412. https://doi.org/10.1108/MD-01-2016-0007 